\title{
ON THE DEVELOPMENT OF TEXTUAL COMPETENCE IN PRIMARY EDUCATION
}

\author{
ADRIANA CARDOSO, SUSANA PEREIRA, \\ ENCARNAÇÃO SILVA, \& OTÍLIA SOUSA
}

\author{
School of Education, Polytechnic Institute of Lisbon, Portugal
}

\begin{abstract}
The aim of this article is to present the results of an action research project, which has been put into practice in Primary Education. This project was intended to develop students' textual competence, considering both comprehension and textual production. Our starting hypothesis was that teaching the schematisation of text types, focusing on linguistic devices that underlie text production, would promote the development of textual competence, leading to the production of more coherent and cohesive texts. In order to test this hypothesis we implemented the project in three phases. First, before the intervention, we collected texts produced by the students. Secondly, we implemented a didactic program designed to develop students' textual competence. Lastly, after the intervention, we collected students' texts once again. Data was analyzed according to categories that confer cohesion and coherence to different types of texts. Narrative, descriptive, and explanatory texts were assessed in terms of 1) building an autonomous text; 2) hierarchisation of information, and 3) textual organisation. Overall, results indicate that students developed their text conceptualisations, their understanding of the different structures of texts, and produced better writing. Indeed, their written work shows a marked progression from the beginning of the intervention program to the end of the program.
\end{abstract}

Key words: text types, narrative, descriptive, and explanatory texts; textual competence, Portugal.

Cardoso, A., Pereira, S., Silva, E., \& Sousa, O. (2009). On the development of textual competence in primary education. L1 - Educational Studies in Language and Literature, 9(4), 63-86.

(C) International Association for the Improvement of Mother Tongue Education

Correspondence concerning this article should be directed Otília Sousa, Escola Superior de Educação de Lisboa, Instituto Politécnico de Lisboa, Campus de Benfica do IPL, 1549 -003 Lisboa, Portugal, Phone: 00351 217115500.E-MAIL otilias@eselx.ipl.pt 
Chinese

[Translation Shek Kam Tse]

论小学教育中语篇能力的发展

摘要: 本文目的在于呈现一项在小学实行中的行动研究计划的结果。该计划旨在发展学生在语篇

理解与表达方面的能力。研究最初设想为: 教学生各种语篇类型, 着重语篇表达为基础的语言手段

能够提高学生语篇能力的发展, 导致生成更加连贯衔接的语篇。为测试该设想, 研究者从三个阶

段实施计划：第一阶段，介入前，收集学生生成的语篇；第二阶段，实施旨在发展学生语篇能力

的教学课程; 最后, 介入后, 再次收集学生的语篇。按照不同语篇类型衔接连贯范畴分析数据。

叙述性，描述性，解释性语篇根据以下角度给予评估：1) 建立独立语篇；2) 信息层次化；3）

语篇组织。结果显示, 从总体来看学生发展了语篇概念和对不同语篇结构的理解, 并发展了更好

的写作能力。的确, 研究对象的写作从研究计划介入开始到结束整个过程中显示出明显的进步。

关键词：语篇类型，叙述性，描述性，解释性，语篇能力，葡萄牙

Dutch

[Translation Tanja Janssen]

TITEL. Over het ontwikkelen van tekstuele competentie in het basisonderwijs.

SAMENVATTING. Dit artikel heeft ten doel de resultaten te presenteren van een actie-onderzoek dat uitgevoerd is in het basisonderwijs. Dit project was bedoeld om de tekstuele competentie van leerlingen te ontwikkelen., zowel teksbegrip als tekstproductie. Onze eerste hypothese was dat onderwijs in tekstschema's, gericht op de talige middelen die aan tekstproductie ten grondslag liggen, de ontwikkeling van tekstuele competentie zou bevorderen, leidend tot het produceren van meer coherente en cohesieve teksten. Om deze hypothese te toetsen implementeerden wij een project in drie fasen. Eerst verzamelden we teksten van leerlingen, voor de interventie. Daarna voerden we een didactisch programma uit, gericht op het ontwikkelen van de tekstuele competentie van leerlingen. Tenslotte verzamelden we opnieuw teksten van leerlingen, na de interventie. Data werden geanalyseerd aan de hand van categorieën die cohesie en coherentie toekenden aan teksten. Narratieve, beschrijvende en verklarende teksten werden beoordeeld in termen van 1) de opbouw van een autonome tekst, 2) hiërarchische informatie, 3) tekstorganisatie. Al met al wijzen de resultaten erop dat leerlingen hun beeld van teksten en hun inzicht in verschillende tekststructuren ontwikkelden en dat zij betere teksten schreven. Hun geschreven teksten zijn aanmerkelijk verbeterd tussen het begin en het einde van de interventie.

TREFWOORDEN: teksttype, narratieve, beschrijvende en verklarende teksten, tekstuele competentie, Portugal.

Finnish

[Translation Katri Sarmavuori]

TITTELI. TEKSTUAALISEN KOMPETENSSIN KEHITYKSESTÄ PERUSKOULUSSA

ABSTRAKTI. Tämän artikkelin tarkoituksena on esittää toimintatutkimuksen tulokset, jotka on saatu peruskoulusta. Hankkeessa on tarkoituksena edistää oppilaiden tekstuaalista kompetenssia, joka sisälsi sekä ymmärtämisen että tekstuaalisen tuottamisen. Lähtöhypoteesina oli, että tekstityyppien skematisoinnin opetus, tekstin tuottamisen kielellisten apukeinojen tarkastelu, edistäisi tekstuaalista kompetenssia, johtaisi tekstien parempaan kompetenssiin ja koheesioon. Tämän hypoteesin testaamiseksi hanke jaettiin kolmeen vaiheeseen. Ensin ennen interventiota keräsimme oppilaiden tuottamat tekstit.

Toiseksi laadimme didaktisen ohjelman oppilaiden tekstuaalisen kompetenssin kehittämiseksi. Lopuksi intervention jälkeen keräsimme jälleen oppilaiden tekstit. Tiedot analysoitiin kategorioihin, jotka koskivat eri tekstityyppien koheesiota ja koherenssia. Narratiiviset, deskriptiiviset ja eksplanatiiviset tekstit arvioitiin sen mukaan, miten ne 1) muodostivat autonomisen tekstin, 2) informaation hierarkisoitumisen ja 3) tekstuaalisen organisaation. Kaiken kaikkiaan tulokset osoittavat, että oppilaat kehittivät tekstikäsitteensä, ymmärryksensä tekstin eri rakenneosista ja tuottivat parempaa kirjoitusta. Kirjoitetut työt osoittavat selvää edistymistä interventio-ohjelman alusta sen loppuun.

AVAINSANAT: Tekstityypit, kertovat, kuvailevat ja ekspositoriset tekstit; tekstuaalinen kompetenssi, Portugali. 
French

[Translation Laurence Pasa]

TITRE. LE DÉVELOPPEMENT DES COMPÉTENCES TEXTUELLES DANS L'ENSEIGNEMENT PRIMAIRE

RESUME. Cet article présente les résultats d'un projet de recherche-action mis en ouvre dans l'enseignement primaire. Ce projet vise le développement des compétences textuelles chez les élèves, tant du point de vue de la compréhension que de la production de textes. Selon notre hypothèse de départ, un enseignement de la structure des différents types de texte centré sur les indices linguistiques qui soustendent la production textuelle, peut promouvoir le développement des compétences textuelles et ainsi conduire à des productions plus cohérentes et plus cohésives. Pour tester cette hypothèse, nous avons mis en œuvre un projet en trois phases. Dans un premier temps, avant l'intervention, nous avons recueilli des textes produits par les élèves. Dans un second temps, nous avons mis en place une intervention didactique conçue pour développer leurs compétences textuelles. Enfin, après l'intervention, nous avons recueilli de nouveaux textes d'élèves. Les données ont été analysées du point de vue de la cohésion et de la cohérence des différents types de textes. Le récit, les textes descriptifs et explicatifs ont été évalués en termes de 1) élaboration d'un texte autonome, 2) hiérarchisation des informations et, 3) organisation textuelle. De façon générale, les résultats indiquent que les élèves ont développé leurs conceptualisations du texte, leur compréhension des différentes structures de textes et ont mieux écrit. En effet, leurs productions écrites témoignent d'une progression importante entre le début et la fin du programme d'intervention.

MOTS-CLÉS : types de texte, récit, textes descriptifs et explicatifs, compétences textuelles, Portugal.

\section{German}

[Translation Ulrike Bohle]

TITEL. Zur Entwicklung von Textkompetenz in der Primarstufe.

ZUSAMMENFASSUNG. Der Artikel präsentiert die Ergebnisse eines Action Research Project, das in der Grundschulausbildung durchgeführt wurde. Das Projekt zielte auf die Entwicklung sowohl der rezeptiven als auch der produktiven Textkompetenz von Schülern. Unsere Ausgangshypothese war, dass das Lehren einer Schematisierung von Textsorten, wobei das Augenmerk auf die sprachlichen Mittel der Textproduktion gerichtet wird, die Entwicklung von Textkompetenz vorantreiben und zur Produktion von Texten mit stärkerer Kohäsion und Kohärenz beitragen würde. Um diese Hypothese zu testen, wurde das Projekt in drei Phasen durchgeführt. Vor der Intervention wurden zunächst Texte der Schüler eingesammelt. In der zweiten Phase wurde ein didaktisches Programm zur Entwicklung der Textkompetenz der Schüler implementiert. Nach der Intervention wurden nochmals Schülertexte eingesammelt. Die Daten wurden nach Kategorien analysiert, die Kohäsion und Kohärenz auf verschiedene Textsorten beziehen. Narrative, deskriptive und explanative Texte wurden mit Blick auf die Konstitution eines autonomen Textes, die Hierarchisierung von Informationen sowie die Textorganisation bewertet. Insgesamt zeigen die Ergebnisse eine Entwicklung der Schüler in der Konzeptualisierung von Texten und im Verständnis für unterschiedliche Textstrukturen sowie eine Verbesserung ihrer Texte. In der Tat zeigen die schriftlichen Arbeiten einen deutlichen Fortschritt im Verlauf des Interventionsprogramms.

SCHLAGWÖRTER: Textsorten, narrative, deskriptive und explanative Texte/Erzählungen, Beschreibungen und Erklärungen, Textkompetenz, Portugal.

\section{Greek}

[Translation Panatoya Papoulia Tzelepi]

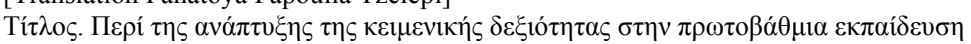

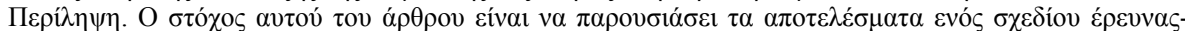

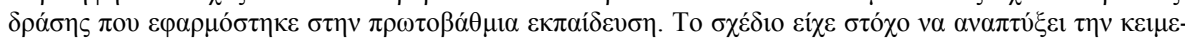

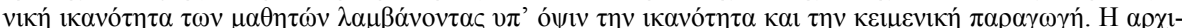

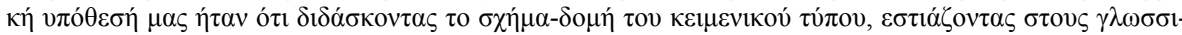

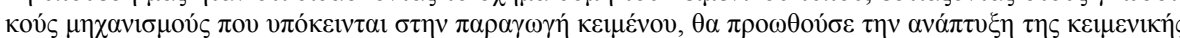

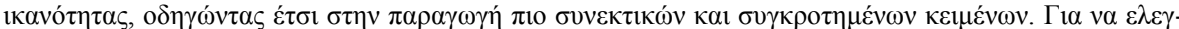

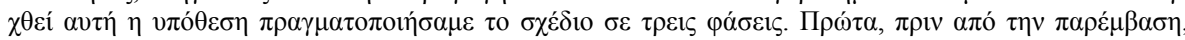

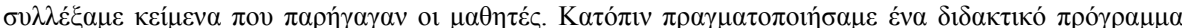

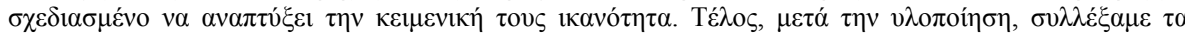

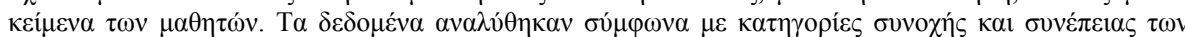

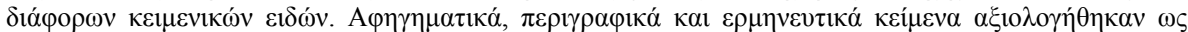




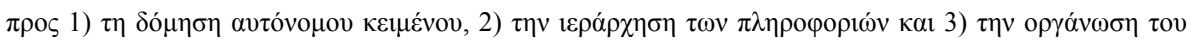

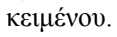

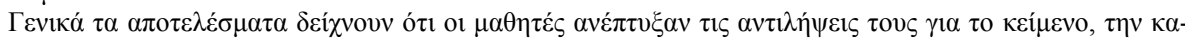

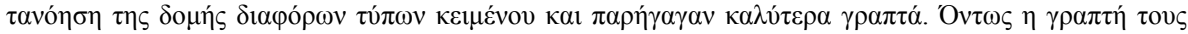

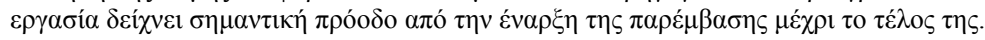

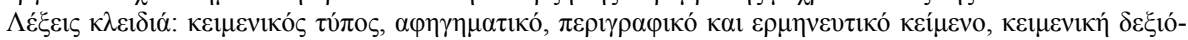

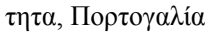

\section{Italian}

[Translation Manuela Delfino, Francesco Caviglia]

TITOLO. Sullo sviluppo delle competenze testuali nella scuola primaria

SOMMARIO. L'obiettivo di questo articolo è presentare i risultati di un progetto di ricerca-azione che è stato attuato nella Scuola primaria. Questo progetto aveva l'obiettivo di sviluppare le competenze testuali degli studenti, tenendo in considerazione sia fattori di comprensione che di produzione testuale. La nostra ipotesi di partenza era che insegnare a schematizzare le tipologie testuali, focalizzandosi sui meccanismi linguistici che sottostanno la produzione del testo, avrebbe promosso lo sviluppo di competenze testuali, portando alla produzione di testi più coerenti e coesi. Per testare questa ipotesi abbiamo organizzato il progetto in tre fasi. Nella prima, prima dell'intervento, abbiamo raccolto i testi prodotti dagli studenti. Poi abbiamo implementato un programma didattico ideato per sviluppare le competenze testuali degli studenti. Infine, dopo l'intervento, abbiamo raccolto nuovamente testi prodotti dagli studenti. I dati sono stati analizzati in base a tre categorie che attribuiscono coesione e coerenza ai diversi tipi di testo. Testi di tipo narrativo, descrittivo e esplicativo sono stati valutati in termini di 1) costruzione di un testo autonomo; 2) organizzazione gerarchica delle informazioni; e 3) organizzazione del testo. Nell'insieme, i risultati indicano che gli studenti hanno sviluppato autonome concettualizzazioni del testo e comprensione delle diverse strutture dei testi e che hanno prodotto degli scritti migliori. Infatti, il loro lavoro scritto mostra un sensibile progresso nella produzione testuale dall'inizio alla fine del programma di intervento.

PAROLE CHAIVE: Tipi di testo; testo narrativo, descrittivo e esplicativo; competenza testuale; Portogallo.

\section{Polish}

[Translation Elżbieta Awramiuk]

TITUŁ. Rozwijanie kompetencji tekstowej w szkole podstawowej

STRESZCZENIE. Celem niniejszego artykułu jest zaprezentowanie wyników projektu badawczego realizowanego w szkole podstawowej. Projekt został zaplanowany, by rozwijać umiejętności uczniów w zakresie rozumienia i tworzenia tekstu. Nasza wstępna hipoteza zakładała, że nauczanie schematów typów tekstów i koncentrowanie się na lingwistycznych środkach wyrazu, które leżą u podłoża tworzenia tekstu, będzie sprzyjać rozwojowi kompetencji tekstowej, prowadząc do pisania tekstów bardziej zwartych i spójnych. Weryfikacja hipotezy nastapiła podczas realizacji projektu w trzech fazach. Najpierw, przed interwencją, zebraliśmy teksty pisane przez uczniów. Następnie wprowadziliśmy program dydaktyczny, którego celem był rozwój uczniowskich kompetencji tekstowych. Na koniec, po interwencji, ponownie zebraliśmy uczniowskie teksty. Dane zostały zanalizowane zgodnie z kategoriami, które przypisują zwartość i spójność różnym typom tekstów. Teksty narracyjne, opisowe i wyjaśniające były oceniane pod względem 1) budowania autonomicznego tekstu, 2) hierarchizowania informacji i 3) organizacji tekstu. Ogólnie wyniki potwierdzają, że uczniowie rozwinęli swe myślenie o tekście, rozumienie różnych struktur tekstowych i tworzyli lepsze teksty. Faktycznie ich prace pisemne są dowodem ogromnego postępu, jaki nastąpił między etapem początkowym programu a jego końcem.

SLOWA-KLUCZE: rodzaje tekstów; teksty narracyjne, opisowe i wyjaśniające; kompetencja tekstowa; Portugalia

\section{Portuguese}

[Translation Sara Leite]

TITULO. Sobre o desenvolvimento da competência textual no ensino básico

RESUMO. O objectivo deste artigo é apresentar os resultados de um projecto de investigação-acção posto em prática no ensino básico. Este projecto pretendia desenvolver a competência textual dos alunos, em termos de compreensão e de produção de textos. A nossa hipótese inicial era a de que o ensino da esquematização de tipos de texto centrada nas marcas linguísticas subjacentes à produção textual promoveria o desenvolvimento da competência textual, levando à produção de textos mais coerentes e 
coesos. Para testar esta hipótese, implementámos o projecto em três fases. Primeiro, antes da intervenção, coligimos textos produzidos pelos alunos. Numa segunda fase, implementámos um programa didáctico destinado a desenvolver a competência textual dos alunos. Finalmente, após a intervenção, voltámos a coligir textos dos alunos. Os dados foram analisados de acordo com uma categorização que confere coesão e coerência a diferentes tipos de texto. Os textos narrativos, descritivos e explicativos foram avaliados em termos de 1) construção de um texto autónomo; 2) hierarquização da informação, e 3) organização textual. De uma maneira geral, os resultados indicam que os alunos desenvolveram as suas conceptualizações textuais e o seu conhecimento sobre as diferentes estruturas textuais, e produziram textos melhores. De facto, os seus trabalhos escritos evidenciam um progresso evidente do início para o fim do programa de intervenção.

PALAVRAS-CHAVE: Tipos de texto, textos narrativos, descritivos e explicativos; competência textual, Portugal.

\section{Spanish}

[Translation Ingrid Marquez]

TÍTULO. Sobre el dearrollo de la competencia en manejo de textos a nivel primario.

RESUMEN. El objetivo de este artículo es presentar los resultados de un proyecto de investigación activa que se ha implementado en el nivel primario. La meta es desarrollar el manejo estudiantil de los textos, tomando en cuenta tanto la comprensión como producción de los mismos. Nuestra hipótesis inicial es que enseñar la esquematización de tipos de texto, con un enfoque en las herramientas lingüísticas necesarias para producir un texto, promovería el desarrollo de la competencia en textos, conduciendo a la producción de textos más coherentes y cohesivos. Para probar esta hipótesis, implementamos un proyecto de tres etapas. Primero, antes de la intervención, recopilamos textos producidos por los estudiantes. En segundo lugar, lanzamos un programa didáctico diseñado para mejorar la competencia textual de los jóvenes. Por último, después de la intervención recopilamos los textos estudiantiles nuevamente. Los datos se analizaron de acuerdo con las categorías que confieren la cohesión y coherencia a diferentes tipos de texto. Los documentos narrativos, descriptivos y explicativos se evaluaron en cuanto a 1) la construcción de un texto autónomo; 2) la jerarquización de la información; y 3) la organización general. A grandes rasgos, los resultados indican que los estudiantes lograron desarrollar una conceptualización de los textos, una comprensión de las diferentes estructuras que forman un texto y un mejor manejo de la escritura propia. De hecho, sus trabajos escritos muestran un progreso marcado que empezó al principio del programa de intervención y siguió hasta el final.

PALABRAS CLAVE: Tipos de texto, textos narrativos, descriptivos y explicativos; competencia en textos, Portugal.

\section{INTRODUCTION}

Both national and international evaluations have consistently shown that Portuguese students are poor readers (PISA 2003/2006- Programme for International Student Assessment). Their achievement in writing is also problematic: at the end of grade 4 less than half the students were considered good writers; at the end of grade 6 only $37 \%$; at the end of grade 9 only $12 \%$ (cf. Ucha, 2007).

The Portuguese educational system is oriented by two main documents: the $\mathrm{Na}$ tional Curriculum for Basic Education, where general objectives and competences are described, and the Curriculum for Basic Education - Essential competences, an attempt to clarify the first document (Departamento da Educação Básica, [1998] 2004; Departamento da Educação Básica, 2001). However, in spite of the description of general objectives and competences, there are no established benchmarks defining achievement levels for speaking, writing and reading by grades or by cycles.

As far as textual competence is concerned, it is important to highlight that there are no definitions of the achievements that should be attained in each cycle of educa- 
tion, namely with respect to the development of textual representation. The lack of clarifying achievement criteria related to textual competence can be perceived from the National Curriculum and from observations of classroom practices.

However, the development of textual competence is an important domain in mother tongue education. The primary school years correspond to a crucial period in the emergence of textual coherence and cohesion (Hickmann, 2003). In particular, it is during these years that students develop new writing functions with specific linguistic devices (Karmiloff-Smith, 1986, Hickmann, 2003) and acquire knowledge of text types (Fayol, 2000).

\subsection{Text and textuality}

In observing speech acts in their written form, we adopted the notion of text as a product and a process, which can be defined as “(...) any passage, spoken or written, of whatever length, that does form a unified whole" (Halliday \& Hasan 1995, p. 1). In other words, text is regarded as a sum of contextualised sentences or utterances with a specific structure (Van Dijk, 1980).

In the literature, text has been defined as a communicative event which meets seven standards of textuality: cohesion, coherence, intentionality, acceptability, informativity, situationality, and intertextuality (De Beaugrande \& Dressler, 1981).

Two of these standards seem to be a determinant of writing proficiency: cohesion and coherence. Cohesion designates the network of lexical, grammatical, and other relations that provide links between various parts of a text. Halliday and Hasan (1995) establish five cohesion categories: reference, substitution, ellipsis, conjunctions, and lexical cohesion. Like cohesion, coherence is a network of relations which organise and create a text. However, whereas cohesion is a result of the connected terms and sentences, coherence is the network of conceptual relations which underlie the surface text. According to Van Dijk (1986), coherence is “(...) a semantic property of discourses, based on the interpretation of each individual sentence relative to the interpretation of other sentences" (p. 93).

\subsection{Textual competence}

The recognition that a text is not merely a result of the juxtaposition of sentences had an important consequence: the production and comprehension of texts started to be seen as intrinsically related to textual competence.

Textual competence can be characterized as the ability to comprehend, use and produce different kinds of multimodal texts, which we meet and produce in every day life. When it comes to education in the mother tongue, the concept of textual competence can be defined as: "(...) the ability to use a broad set of dynamic and changeable textual assumptions that allow one receptive and productive to glide through multimodal texts with an understanding, commitment and critical distance" (Slot, 2006, p. 479).

As Fterniati and Spinthourakis (2004) point out, many factors determine this ability. For instance, they suggest that individuals who possess few textual schemata 
develop difficulties in their attempts to understand or produce discourse (Bereiter \& Scardamalia,1987).

\subsection{Schema theory and text types}

The schema concept is attributed to Bartlett (1932), who claims that people's understanding of events is shaped by their expectations or prior knowledge. These expectations are presented mentally in some sort of schematic fashion (Ajideh, 2003).

Generally, there are three major types of schemata: linguistic schemata, formal schemata and content schemata. As far as text types are concerned, formal schemata play an important role, since they include knowledge of discourse structure and conventions. More concretely, they also include the knowledge that text organisation, language structures, vocabulary, grammar and level of formality are used differently according to each specific text type (Li et al., 2007).

From the view point of text-oriented theories, there are some similarities between formal schemata and the concept of textual prototypes. The prototype serves as a "superstructure" that guides the writer's linguistic choices, dictating various conventions. Superstructures are conventional structures that refer to the organisation of information at text level. They summarise the textual constituents and provide information about ordering and hierarchical relations within a specific text type.

In this context, it is worth noting that text is not a homogeneous sequential structure. On the contrary, it has a heterogeneous nature in which, among the variation, one can find compositional regularities that are realized in prototypical sequences (Adam, 1992).

Since in this study we will focus on narrative, descriptive and explanatory texts, in the following section we will outline the structure of these text types.

\section{1..1 The narrative, descriptive and explanatory text types}

Narrative seems to be the most universal genre, because all cultures have story telling traditions. A narrative can be defined "(...) as one method of recapitulating past experience by matching a verbal sequence of clauses to the sequence of events which (it is inferred) actually occurred" (Labov, 1972, p. 361). Adam (1993), following Larivaille (1974), suggests five macro-propositions in the narrative sequence: abstract, initial situation, complication, reaction and resolution. Hence, the narrative template may include the following components: an abstract, a sort of title for the story; the orientation (including time, place and character identification); the goal and the problem; the steps to resolve the problem (a set of temporal causal ordered clauses); the resolution.

The descriptive sequence comprises two main macro-propositions: localisation or anchoring and aspectualisation (Adam \& Petitjean, 1989). The localisation procedure is the descriptive text first organising device. It assures the semantic-referential 
cohesion of the text through an adequate title-theme ${ }^{1}$ (Adam \& Petitjean, 1989 and Adam, 1992). The title-theme is usually a nominal expression. By resorting to this nominal-pivot, the enunciator indicates who or what will be at stake. The second procedure, aspectualisation, comprises the sectioning of a whole - identified by the title-theme - in its constitutive parts. Along with the presentation of its parts, the properties and features of the whole are considered (colour, size, shape, etc.). Through new sectioning operations the properties of the parts may also be presented.

As far as the structure of the explanatory sequence is concerned, Adam (1992) proposes a structure with four macro-propositions:

0.

Explanatory macro-proposition 0 : Initial schematisation

1. Why? How? Explanatory macro-proposition 1: Problem (question)

2. Because Explanatory macro-proposition 2: Explanation (answer)

3. Explanatory macro-proposition 3: Conclusion-evaluation

The 'Explanatory macro-proposition 0 ' does not necessarily appear in the explanation and it corresponds to an introduction that situates the problem. The 'Explanatory macro-proposition 1' can be actualized by the operator 'Why' and corresponds to the formulation of the problem (which can occur either explicitly or implicitly in the text.) The 'Explanatory macro-proposition 2' can be actualized by the operator 'because' and is regarded as the answer to the problem. Finally, the 'Explanatory macro-proposition 3 ' is a conclusion that generalises the explanation.

\subsection{From theory to practice}

As already mentioned, the difficulties faced by students during text production are due, among other factors, to the lack of awareness of basic parameters which determine the production of each specific text type (Fterniati \& Spinthourakis, 2004).

According to Chapman (1995), children construct their knowledge of textual types from their literacy environments. Contrary to this, some authors consider that the social context is not enough for the optimal development of these skills, since some text types (namely those related to academic subjects) are not available in the immediate social context, and, consequently, are more difficult to learn (Chapman, 2006).

For this reason, it is necessary to promote explicit instruction of texts types. The integration of explicit strategy instruction within the process approach to writing should be linked to children's contact with the written culture. That is why in this

\footnotetext{
${ }^{1}$ The title-theme activates a virtual reference (Milner, 1982), identified with the (tested) collective encyclopaedic knowledge and, therefore, independent from the situational context, which will be updated through the aspectualisation procedure.
} 
study we adopted a nuanced and contextual approach, considering both the children's background and the written culture they are exposed to (Smagorinsky, 2006).

On the other hand, the adoption of a text typology, which organises texts according to prototypic schemes, is due to the fact that students are integrated in communities that have little contact with the writing process. Considering the three text types, which are the object of our study, the narrative prototypic scheme is the only one which students are exposed to from an early age. With the remaining types, that is not the case, at least not that frequently. As widely referred to in the literature, this situation leads to a lack of knowledge of textual schemes and, consequently, to problems regarding both text production and text comprehension (Englert \& Thomas, 1987; Dickson, Simmons \& Kameenui, 2007).

If, as Adam (1992) suggests, oral and written text comprehension difficulties may be partly explained by a lack of knowledge of prototypic textual schemes, this work is fully justified. The application of the project in second through fourth grades, with adequate pedagogic-didactical strategies, may serve to indicate how we can improve students' writing skills.

Although the project is structured according to text types, we believe that in the classroom teachers should adopt a more global approach. The teaching of text types should be integrated in a wider understanding of texts and not viewed as the sole prescriptive approach students are exposed to.

\section{PURPOSE}

This article presents and discusses the results of the Project Reading \& Writing - for a textual typology, created to enhance the development of textual competence in the 1st Cycle of Primary Education. The project aimed to:

- Assess pupils' textual competence, identifying the areas in which they had more difficulties;

- Outline a pedagogical intervention, based on a theoretical framework;

- Establish whether pupils improved the development of their textual competence.

Our premise was that building a textual conscience and a reflexive attitude based on what texts have in common promotes the development of competences concerning reading comprehension and related text production.

Therefore, the following principles guided our inquiry:

- Reading and writing a coherent text demands a wide knowledge of texts and of the criteria that underlie their organisation;

- Producing a text is a social, strategic process, with specific aims and subject to different constraints, which need to be clarified;

- When writing a text the pupil is always under a "mental overload". Due to the complexity of the act of writing (Fayol, 1986), it is necessary to limit the child's "mental overload", helping him/her in every step of text production. 


\section{METHOD}

The Project Reading \& Writing - for a textual typology, was implemented as a year-long study carried out between September and July by investigators from the Escola Superior de Educação de Lisboa (Lisbon's School of Education) with the financial support of the Instituto de Inovação Educacional (Institute for Educational Innovation).

\subsection{Participants}

The subjects of our study were 120 pupils from the second, third and fourth grades of the $1^{\text {st }}$ Cycle of Primary School. The participating students were distributed between six urban schools located in areas on the outskirts of the metropolis; with one classroom of about 20 students per school and a total of six teachers. From a socio-economic point of view, the schools and classes may be classified as medium-low. The teachers who collaborated attended in-service training in the Escola Superior de Educação (state-financed teacher training facility).

\subsection{Tasks and Procedure}

The phases of the Project developed as follows:

- September - theoretical and methodological preparation;

- October - first data collection (henceforth referred to as Corpus 1)

- November to December - analysis of Corpus 1 and training/reflection with the collaborating teachers;

- January to May - project application in schools;

- June - second data collection (henceforth referred to as Corpus 2)

- July to September - analysis of Corpus 2 data and comparison with the data obtained in Corpus 1.

\subsubsection{Initial Diagnosis}

The initial diagnosis was based on a collection of a corpus of written narrative, descriptive and explanatory texts ${ }^{2}$. The stimulus and instructions used were the following:

Narrative text. Stimulus: Retelling the story The green bird from Alice Vieira (Ed. Caminho); Instruction: "You will listen very carefully to a story. Then we are going to ask you to tell the story you have heard in writing".

\footnotetext{
${ }^{2}$ CINDEI (Digital supported Corpus of Narrative, Descriptive and Explanatory/Informative Texts) is composed by 230 narrative texts, 230 descriptive texts and 230 explanatory/informative texts, produced by students in $2^{\text {nd }}, 3^{\text {rd }}$ and $4^{\text {th }}$ grades.
} 
Descriptive Text. Stimulus: Describing a picture (See Figure 1). Instruction: "Look at the picture very carefully. Now you will describe in writing what you see in the picture."

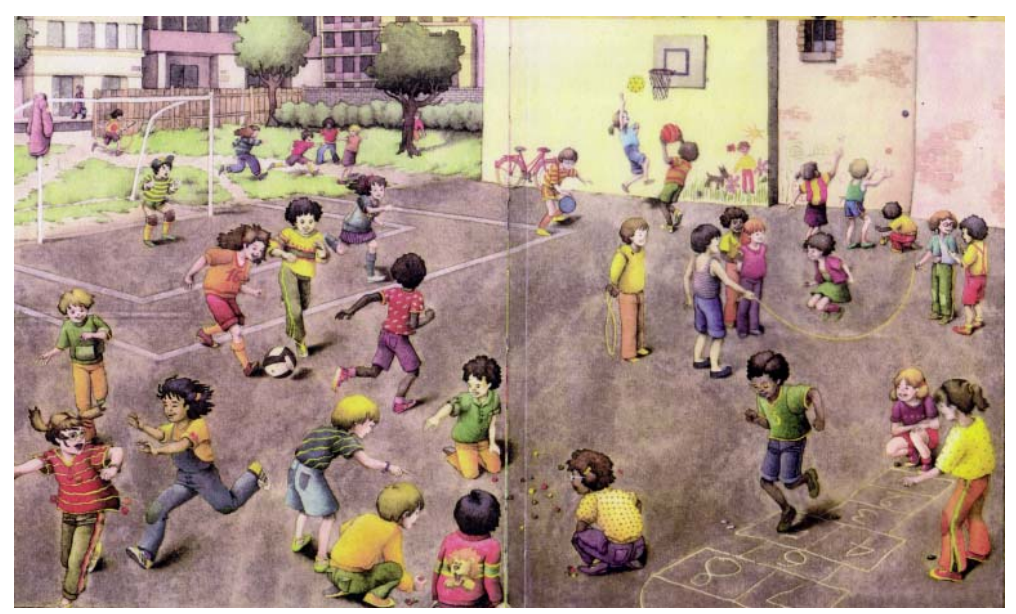

Figure 1. Stimulus for Descriptive text

Explanatory text. Instruction: "Explain in your own words why the moon doesn't always look the same".

\subsubsection{Application planning}

Following the analysis of the texts gathered, a training programme for the teachers was established regarding the teaching of the different types of texts. With the aim of developing students' textual competence, reading and writing connections were emphasized as materials to be used in the classrooms were designed.

\subsubsection{Application in classes}

The teachers discussed with their students the learning strategies and knowledge that could be applied by pupils, at different grade levels, to reading and writing situations. In teaching situations, we always started by offering students meaningful contexts from which to view writing as a purposeful activity. In order to provide a reason for writing we created situations that implied producing the text types in question. The application of the didactic sequences in classes occurred according to the following principles and steps:

1. Reading different texts with different communicative intentions. Our goal was to make students understand the text diversity used in the different communicative genres. Progressively they should be capable of understanding that there is an under- 
lying intention/aim and audience for any text. In this phase, students were invited to bring different texts to the classroom. The texts were read and questions asked in joint interaction between students and teachers. The teachers also brought in texts that they found appropriate, mainly to illustrate the selected types: narrative texts (stories), descriptive (encyclopaedia entries describing animals, descriptions of people, animals, places, images) and explanatory (recipes, directions, science and history texts). The texts were read and the students invited to deduce: (1) When (in which circumstances) we read/listen to similar texts; (2) What their function is.

2. Listening comprehension (where teacher reads to pupils) / Reading different types of texts in order to build textual awareness. In this phase students accounted for their prior knowledge regarding texts and read different types of texts, which were chosen as being exemplary. It was intended that, through reflection in interaction, students would understand the conceptualisation of the different organisational schemes underlying the different types of texts. In this phase one of the main strategies (although not the only one) was organising several reading workshops for the different types of texts. Classes were divided into groups, with each group preparing the reading of a different text, although every text was the same type. Afterwards, each group read their text to the larger group and a teacher-led discussion followed. Children, along with the teacher, accounted for their prior knowledge regarding texts and subsequently identified the new knowledge acquired. They could thus build the text's Identity Card, according to the text type in question (taking into account pragmatic and enunciation criteria). In some sessions, there was also a moment for filling in grids or elaborating posters, where conclusions were registered.

3. Producing the different text types, favouring the diversity of the triggers and optimising reading and writing situations, in which text production was integrated in appropriate communicative contexts. In this phase, we intended children to produce different types of texts and to this end writing workshops were organised.

In brief, the pedagogic itinerary described thus far may be represented as follows: reading/listening

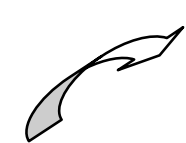

reconstructing

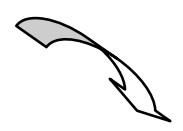

reflecting
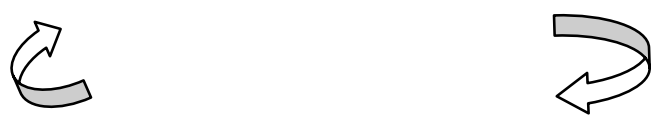

reflecting constructing

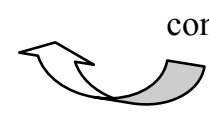


Valuing a view of writing as a process was always a concern. Therefore, in small or large group situations, there were moments for: (i) clarifying who writes / whom he/she writes to / to what effect; (ii) deciding what to write and (iii) planning how to write (what to write in the first, second, third paragraphs, etc.). We wanted students to progressively consider textualisation as a process (Hayes \& Flower, 1980; Hayes, 1996), which implies constructing and reconstructing (Negro \& Chanquoy, 2005). Students made text revisions after reading their writing to the class and incorporated comments from their peers, possibly followed by a rewriting proposal.

Oral discussions on writing activities (text deconstruction, planning, composition, revision) aimed, on the one hand, at identifying the important questions concerning textualisation principles and, on the other hand, at clarifying processes and behaviours to be adopted. We favoured a developmental approach in which, through sharing and verbalisation, we intended to build knowledge and to acquire competences in text production and comprehension. As an ultimate aim, we intended to create a community engaged in text production and comprehension, sharing a specific knowledge and a common language, which would enable an approach to the written code adequate to the tasks and problems to be solved (Hayes, 1996).

\subsubsection{Comparing the texts produced}

Following the application of the didactic procedures in the classroom, students were asked to produce texts once again, according to the initial stimuli. The analysis of Corpus 2 enabled identification of improvements in the subjects' texts. Comparing texts from Corpus 1 and 2 enabled an evaluation of the improvements from the intervention. The next section is based on this comparison.

\section{RESULTS}

The results of this study have been partially published, according to the type of text involved (Sousa \& Silva, 2003a, 2003b; Costa \& Pereira, 2003; Pereira \& Costa, 2003; Cardoso \& Silva, 2003a, 2003b). Within the scope of this article, we present the main findings obtained as far as development of textual competence is concerned. Therefore, we will focus on the changes that have been found by comparing Corpus 1 and 2 in relation to the following analytical categories: (1) Building an autonomous text; (2) Hierarchisation of information, and (3), Using textual organisers.

\subsection{Building an autonomous text}

A text is a unified and cohesive whole produced in a given discourse mode. Thus, it requires different underlying competences. That is, in order to produce a text that facilitates comprehension it is necessary for the writer to develop the following: (1) An evaluation of the reader's expectations and a set of pre-reading questions the reader may be interested in and that our text should answer; (2) An awareness that 
the information is unknown to the reader; (3) An evaluation of the reader's point of view.

On the other hand, a text must be autonomous, or it must create its own sphere of reference, no matter what situation it enunciates. That is why it may be stated that a text is necessarily auto-referential, since it must contain all the necessary referential information necessary for its interpretation. In the narrative text, the creation of an autonomous universe is usually set by phrases such as Once upon a time. By resorting to this opening formula, the enunciator creates a detached enunciation domain, different from the here and now. In the descriptive text, the localisation guaranteeing semantic-referential cohesion of the text is often marked by a nominal expression, corresponding to the so-called title-theme. In the explanatory text some authors (Adam, 1992) consider that before the explanatory presentation itself, there should be an introduction to the subject matter, followed by an explicit presentation of the problem (respectively explanatory macro-proposition 0 and 1 ). Thus, although the referential autonomy requirement to building any text is transversal, the linguistic strategies to be adopted differ according to the different types of text.

In the texts produced by students in Corpus 1, the difficulty in adopting localisation strategies adequate to the text type demanded by the instruction provided by the teacher was significant. As an example, in the descriptive texts of Corpus 1 a significant number of students chose to produce a text using the typical opening formula of the narrative text.

Era uma vez 33 meninos que andavam no recreio (...) / Quando a campainha tucou todos entraram...

Once upon a time there were 33 children who were playing in the playground (...) When the bell rang they all went in... (Corpus $1,3^{\text {rd }}$ year)

The same tendency appears when producing explanatory texts. Thus, before the instruction, (Explain in your own words why the moon does not always look the same) which at the very least required an explanation, (explanatory macro-proposition 2) many pupils produced descriptions instead of explanations.

A lua. / Eu vaiso a lua. / A lua está vasia. / A lua é azul. / A lua é muito bonita. / A lua é brança como o algudão. ${ }^{3}$

The moon./ I see the moon./ The moon is empty./ The moon is blue./ The moon is very beautiful./ The moon is white like cotton. (Corpus $1,2^{\text {nd }}$ year)

\footnotetext{
${ }^{3}$ Changing line is indicated in the examples through ' $/$,, in order to render the examples shorter.
} 
On the contrary, in Corpus 2 there is no interference of other text types in the construction of the text's autonomous reference. Moreover, as far as textual autonomy is concerned, we underline the main specific difficulties according to each text type.

Narrative Text. The definition of a narrative as an autonomous text assumes the construction of the referential coordinates for time, space and characters. However, in the texts of Corpus 1 the absence of these elements is frequent, mainly among the youngest subjects.

O passaro verde. / A menina matou o passaro. / O Rai foi á caça. / O Rai madou a prissaza para á janela. / A prissaza caio na poça de água. / O passaro foi ajodar á prissaza

The green bird./ The girl killed the bird./ The king went hunting./ The king sent the princess to the window./ The princess fell in the puddle./ The bird helped the princess. (Corpus $1,2^{\text {nd }}$ year)

In this example the subject does not refer the time nor the space coordinates. Although the characters are introduced, the specific linguistic forms are not respected, namely, the use of the indefinite determiner and of the existential predicate. In Corpus 2, due to the development of textual knowledge of narrative texts this problem no longer occurs.

Descriptive Text. In the texts of Corpus 1 it is clear that the omission of the localisation procedure jeopardises the text's semantic-referential cohesion. The following linguistic sequence is indicative in this regard:

Três meninas a jogar a macaca / são seis meninas a / saltar a corda doas neninas a / jogar a apanhada doas / meninas a jogar basquete / sinquos meninos a jogar a bola / quatro meninos a jogar / a estatoa apanhada doas meninas / a jogar a parede sinquo / neninos a jogar as / saltitonas.

Three girls playing hopscotch/ there are six girls/ jumping rope. Two girls/ playing tag and chasing two/ girls playing basketball/ five boys playing ball/ four boys playing/ statue tag and chasing two girls/ playing against the wall five/ boys hopping / (Corpus $1,2^{\text {nd }}$ year)

It is clear in this sequence that the child limits himself/herself to making a list of the constitutive parts of a whole. Reading difficulties naturally emerge, since he/she does not provide any linguistic elements indicative of the overall meaning, such as school, playground, break, etc.

In Corpus 2 there is a noteworthy decrease in the number of omissions of title-theme (from $36,7 \%$ to $0,9 \%$ ). This decrease parallels the increasing number of inadequate title-themes in $2^{\text {nd }}$ year texts, as shown in Table 1. 
It must be stressed that in Corpus 1 the sum of omitted and inadequate title-themes amounts to $54,2 \%$, surpassing the number of adequate title-themes. By contrast, in Corpus 2, there is almost no omission of title-theme and only $29,7 \%$ inadequate choices.

Table 1. Omitted / Inadequate title-themes in descriptive texts

\begin{tabular}{lllllll}
\hline & \multicolumn{3}{c}{ Corpus 1 } & \multicolumn{3}{c}{ Corpus 2 } \\
& $2^{\text {nd }}$ year & $3^{\text {rd }}$ year & $4^{\text {th }}$ year & $2^{\text {nd }}$ year & $3^{\text {rd }}$ year & $4^{\text {th }}$ year \\
& & & & & & \\
\hline Omitted & 34 & 6 & 4 & 0 & 0 & 1 \\
Inadequate & 3 & 15 & 3 & 20 & 13 & 0 \\
Total & 37 & 21 & 7 & 20 & 13 & 1 \\
& & & & & & \\
\hline
\end{tabular}

Explanatory Text. The main difficulty in the texts produced in Corpus 1 is the absence of an initial presentation of the problem to be handled. Additionally, in Corpus 2 there are no improvements as far as the inclusion of an introduction to the explanation. The most significant improvement regarding this text type concerns the presentation of an explanation as a general procedure ('Explanatory macro-proposition 2'), as shown in Table 2:

Table 2. Construction of different levels in descriptive texts

\begin{tabular}{ccc}
\hline Year & $\begin{array}{c}\text { Corpus 1 } \\
\text { Number of texts }\end{array}$ & $\begin{array}{c}\text { Corpus 2 } \\
\text { Number of texts }\end{array}$ \\
\hline $2^{\text {nd }}$ & 4 & 7 \\
$3^{\text {rd }}$ & 7 & 18 \\
$4^{\text {th }}$ & 13 & 21 \\
Total & 24 & 46 \\
\hline
\end{tabular}

On the other hand, there are improvements regarding the level of expansion of the explanatory sequence: while the texts of Corpus 1 contain, in most cases, only the micro-explanation, the Corpus 2 texts have far more detailed explanations. This can be confirmed by contrasting the following texts, produced by the same subject in Corpus 1 and 2 respectively:

Porque esistem varios [tipor] tipos de luas.

Because there are several types of moons. (Corpus $1,4^{\text {th }}$ year) 
Porque é que a lua não é sempre igual? / Porque quando a terra gira á volta do sol a lua leva 29 dias a dar a volta á terra. / Enquanto e terra leva 24 horas (1 dia) a dar a volta ao sol. / Quano a lua está a norte ve-se a lua cheia. / Quando está a sul ve-se lua nova. / E também há o quarto minguante e o quarto crescente. / Á e ainda digo que a lua não tem luz própria.

Why doesn't the moon always look the same? / Because when the earth rotates around the sun the moon takes 29 days to rotate around the earth. / While the earth takes 24 hours ( 1 day) to rotate around the sun. /When the moon is facing north you can watch the full moon./ When it is facing south you can watch the new moon. / And there is also the gibous and the crescent moon./ Oh and I will also add that the moon does not have its own light. (Corpus $2,4^{\text {th }}$ year)

The expansion of the explanatory sequence in Corpus 2 has an impact in the number of words: as depicted in Table 3, the total amount of words increases from 2994 in Corpus 1 to 6967 in Corpus 2.

Table 3. Macro-propositions in explanatory texts

\begin{tabular}{lllllll}
\hline & & \multicolumn{1}{c}{ Corpus 1 } \\
& $2^{\text {nd }}$ year & $3^{\text {rd }}$ year & $4^{\text {th }}$ year & $2^{\text {nd }}$ year & $\begin{array}{c}\text { Corpus 1 } \\
3^{\text {rd }} \text { year }\end{array}$ & $4^{\text {th }}$ year \\
\hline emp0 & 0 & 0 & 0 & 0 & 0 & 0 \\
emp1 & 1 & 32 & 27 & 35 & 37 & 39 \\
emp2 & 11 & 39 & 40 & 34 & 37 & 39 \\
emp3 & 0 & 0 & 0 & 1 & 1 & 1 \\
& & & & & & \\
\hline
\end{tabular}

\subsection{Hierarchisation of the information}

The textualisation operations include selection, categorisation and the hierarchisation of contents, which mobilises both linguistic and conceptual competences. However, this is a rather complex task for students of this age. It is not therefore surprising, that we have found some difficulties in hierarchising information in every text type.

Narrative text. The non-construction of perspective leads to an incipient narrative effect, for although the subjects refer to the narrative's key moments in their texts, they do not produce a narrative effect. The events appear juxtaposed: either through simple juxtaposition of clauses or through excessive connection marking. These connection markers are used to indicate that the narrative space is still open. This excessive connection marking is normally used in association with forms and (e) and then (depois). These forms function as addition markers and, often, they only mark speech succession, that is, they mark a typical feature of language, speech linearity. The excessive use and unique application of this type of marker results in 
consecutive events with no interdependence relations established between them (Sousa, 1996). Thus, as we have already mentioned, the information is not hierarchised and the relevant moments in the narrative progression are not highlighted. It is important to underline that after the intervention this behaviour changed, since there was a progressive detachment from this textual organisation model, in which a linear progression form prevails. In Corpus 2, the narrative texts begin to gain perspective: the events stop being presented at the same level and at the same time, the construction of narrative ruptures becomes more frequent.

Descriptive text. The difficulty in handling the descriptive sequence, given its compositional heterogeneity leads to its frequent association to a simple procedure based on enumeration, with a strictly linear organisation. According to Adam and Petitjean (1989) and Adam (1992), we will, on the contrary, assume that the descriptive organisation has a hierarchical nature. One of the difficulties students show is when constructing different descriptive levels, that is, difficulties in dealing with one of the main characteristics of the descriptive text: hierarchisation. Establishing different descriptive levels was rare in the texts of Corpus 1, since it only occurred in $20 \%$ of the texts. In other words, students take into account the parts of the situation (playtime/playground), but they seldom assume each part as a starting point to establish a new description level, which is formed by parts and by properties. If we consider the data from Corpus 2, there is a significant increase in the number of texts in which this procedure is used, as shown in Table 4:

Table 4. Number of words in explanatory text

\begin{tabular}{ccc}
\hline & $\begin{array}{c}\text { Corpus 1 } \\
\text { Year }\end{array}$ & $\begin{array}{c}\text { Corpus 2 } \\
\text { Number of occurrences }\end{array}$ \\
& & \\
\hline $2^{\text {nd }}$ & 824 & 1652 \\
$3^{\text {rd }}$ & 1252 & 3144 \\
$4^{\text {th }}$ & 918 & 2171 \\
Total & 2994 & 6967 \\
\hline
\end{tabular}

Explanatory text. Also in explanatory texts the categorisation of contents and difficulty with hierarchisation is evident, that is, there is difficulty both in selecting relevant information for explanation, and in imposing a logical, rational path among the selected data. Generally, students do not establish hierarchic relations among the different propositions, juxtaposing and repeating information in an inordinate manner. As Coltier (1986) notes, there are some linguistic devices that are important for the organisation of explanatory texts, namely; nominal anaphors, nominalisations, relative clauses and reformulations. With these lexical and grammatical dependencies, stretches of language are connected to each other, creating coherent explanatory texts. Regarding these elements, improvements are registered in the corpus. In 
Corpus 1: (i) nominal anaphoras are present, but only through repetition of the noun phrase the moon; (ii) nominalisations do not occur; (iii) relative clauses are scarce (1 in the $2^{\text {nd }}$ year; 6 in the $3^{\text {rd }}$ year and 2 in the $4^{\text {th }}$ year); (iv) reformulations do not occur. By contrast, in Corpus 2 the following improvements are found: (i) nominal anaphoras occur and are not limited to the repetition of the noun phrase the moon (e.g. The moon seen from the earth does not look always the same. The part that is seen is illuminated by the sun...); (ii) relative clauses are more frequent ( 9 in the $2^{\text {nd }}$ year; 26 in the $3^{\text {rd }}$ year and 6 in the $4^{\text {th }}$ ); (iii) reformulations occur $\left(1\right.$ in the $3^{\text {rd }}$ year and 2 in the $\left.4^{\text {th }}\right)$. In addition, it is worth noting that there is another factor that may justify the improvement registered in Corpus 2: the fact that, during the school year, students acquired scientific knowledge allowing them to answer the question set in a more informed way. In fact, the importance of the pragmatic conditions for the existence of an explanation is confirmed. According to Grize (1981), there are mainly three pragmatic conditions, in order for speech to be taken as an explanation:

1) The phenomenon to be explained is undeniable and a non controversial fact;

2) The receiver must be led to make a question;

3) The one who explains must be considered competent to do so.

In this case, we consider the third condition above relevant because the students, as knowledge holders, must have felt more competent to produce an explanation.

\subsection{Using textual organisers}

According to Schneuwly, Rosat and Dolz (1989) and Fayol (1997) textual organisers are considered linguistic units. Even if they are not an integral part of the sentence structure, they join the sentences in order to form a sequence, determining their insertion in the co-text or in the production context. Textual organisers comprise conjunctions and adverbial and subjunctive phrases. They are responsible for subordinate and coordination operations, organisation of contents, time and space localisation and linguistic structuring of the text. Their main functions are to connect the different speech segments, to delimit the text into sequences and to facilitate understanding.

From the analysis of the Corpus 2 texts, there is a significant improvement in this respect. Besides a more systematic use of this type of marker, there is also greater diversity, which leads to more coherent and cohesive texts.

Narrative text. Narrative segmentation into sequences is also related to the use of speech markers, namely markers of time rupture and narrative marking. The first are related to the nature of narrative time, since the narrative does not indicate the whole time, it focalizes the time, that is, the relevant times. Narrative markers signal new directions in the narrative universe, often marking unexpected or relevant events in the narrative. Within the texts produced in Corpus 1, there is:

- An absence of rupture markers enabling text delimitation into sequences;

- A total absence of inter-phrasal connection markers;

- An absence of punctuation, namely regarding direct speech and paragraph marking. 
As an example, we shall compare the use of time rupture markers present in the texts of Corpus 1 and 2:

Table 5 - Time rupture markers in narrative text (Number of occurrences)

\begin{tabular}{ccc} 
& $\begin{array}{c}\text { Corpus 1 } \\
\text { Year }\end{array}$ & $\begin{array}{c}\text { Corpus 2 } \\
\text { Nr }\end{array}$ \\
\hline $2^{\text {nd }}$ & 57 & 103 \\
$3^{\text {rd }}$ & 130 & 170 \\
$4^{\text {th }}$ & 158 & 174 \\
Total & 345 & 447 \\
\hline
\end{tabular}

As is noticeable in the table, the improvements between Corpus 1 and 2 are considerable. The second year, in particular, registers the greatest differential in the use of time rupture markers. In the narrative text, these markers are fundamental for the organisation of information, hierarchisation, and for segmenting time and introducing new time, which together allow new events to be stressed from the point of view of narrative economy. The absence or sparse presence of rupture markers leads to a prevalence of texts with a dominant organisation arising from the simple juxtaposition of utterances or from using forms that signal speech linearity. In contrast, a more frequent use of this type of marker enables text to be organised into several sequences or narrative events.

Descriptive text. Using space organisers allows the arrangement of the different parts of a whole in an organised way. Thus, textual organisers are essential for the hierarchisation procedure described in the previous section. This strategy helps to avoid making stereotyped lists, that is, mere enumeration. As Table 6 shows, as far as occurrence of space organisers is concerned (above, on the right, at the back of, etc.) there is a clear contrast between the data from Corpus 1 and 2:

Table 6 - Space organisers in the descriptive text (Number of occurrences)

\begin{tabular}{|c|c|c|}
\hline & Corpus 1 & Corpus 2 \\
\hline Year & No. of occurrences & No. of occurrences \\
\hline $2^{\text {nd }}$ & 0 & 63 \\
\hline $3^{\text {rd }}$ & 5 & 44 \\
\hline $4^{\text {th }}$ & 2 & 143 \\
\hline Total & 7 & 250 \\
\hline
\end{tabular}

The increase in the number of occurrences in the texts from Corpus 1 to Corpus 2 evidences a pronounced progression that, in our view, is difficult to explain had an application of experimental didactic sequences in classes not occurred between the 
first and the second data collection. This situation is due mainly to the students' discovery of the procedures underlying the textualisation of the descriptive sequence, making it possible to resort to these text organisers.

Explanatory text. Finally, taking into account that the explanatory text is marked by a logical organisation, the correct use of text organisers is crucial to produce this type of text. Explanatory texts are formed by "boundary" statements, which guarantee textual unity and cohesion. The relationships between the different parts of the text may be marked by phrases such as: "afterwards", "in the first place", "secondly". On the other hand, textual cohesion may be marked by connectors indicating addition (also, as well), opposition (but, however), and consequence or cause (because, due to) (cf. Coltier 1986). In Corpus 1 texts there is an almost total absence of conclusive connectors, which are crucial to the course of explanation. On the other hand, the cause connector "because" is the most frequently used, being repeated in every text. Its exhaustive repetition is almost a handicap for the elaboration of a good explanation sequence, since students begin their texts immediately with "because", discarding any type of introduction to the problem to be approached. (cf. section 4.1.). By comparing Corpus 1 and 2, one can conclude that there is both an increase in the number of connectors used and in the use of new connectors.

Table 7 - Connectors in the explanatory text per year and corpus.

\begin{tabular}{|c|c|c|c|c|c|c|}
\hline & \multicolumn{3}{|c|}{ Corpus 1} & \multicolumn{3}{|c|}{ Corpus 2} \\
\hline & $2^{\text {nd }}$ year & $3^{\text {rd }}$ year & $4^{\text {th }}$ year & $2^{\text {nd }}$ year & $3^{\text {rd }}$ year & $4^{\text {th }}$ year \\
\hline \multicolumn{7}{|l|}{ Text connectors } \\
\hline Cause (e.g., because) & 11 & 56 & 42 & 31 & 58 & 40 \\
\hline Conclusion (e.g., therefore) & 1 & 3 & 3 & 5 & 15 & 10 \\
\hline Opposition (e.g., but) & 0 & 3 & 4 & 1 & 6 & 3 \\
\hline \multirow[t]{2}{*}{ Addition (e.g., also) } & 12 & 51 & 38 & 51 & 79 & 90 \\
\hline & Total & \multicolumn{2}{|c|}{227} & \multicolumn{3}{|c|}{396} \\
\hline
\end{tabular}

As far as the contrast between Corpus 1 and 2 is concerned, we notice: (1) The occurrence in Corpus 2 of a wider variety of organisers of the text sequence: besides the occurrence of "for example" (por exemplo), there is the occurrence of "on the other hand" (por sua vez), "lastly" (por fim), "first...next" (primeiro... a seguir) and "first...then" (primeiro...depois); (2) The increase, in Corpus 2, of reasoning organisers, mainly of the cause connector "because" (porque), of the conclusive connector "therefore" (por isso) and of the addition connectors "and" (e) and "also" (também). (3) The appearance, in Corpus 2, of a wider variety of reasoning organisers such as "because of this" (por isto) and "thus" (daî).

The almost total absence of text sequence organisers in Corpus 1 texts shows the lack of knowledge of a crucial strategy for the construction of the explanatory sequence. In fact, its use in the Corpus 2 texts leads to the production of more cohe- 
sive texts, since it is possible to control the text's development, signalling the different parts it is composed of.

\section{CONCLUDING REMARKS}

The analysis of textual competences according to different text types suggests that, overall, the students improved their writing skills, producing more cohesive and coherent narratives, descriptive and explanatory texts. This improvement is clear when we compare data from Corpus 1 to data from Corpus 2, namely in what concerns students' ability to construct an autonomous text, to organise information hierarchically, and to use textual organisers. Although these textual devices should be present in all types of texts, they assume a particular role according to the specificities of text types. Thus, we believe that improved writing skills are linked to the students' growing knowledge of the characteristics of each type of text. For example, the hierarchisation of information is a requirement of effective writing in general, but its construction requires linguistic choices that must be adequate to a particular text type.

We believe this work should be continued in subsequent educational cycles $\left(2^{\text {nd }}\right.$ and $3^{\text {rd }}$ Cycles), given that text competence develops throughout secondary education. Based on the results obtained, it seems evident that it is urgent to implement more integrated and systematic text practices. Starting from identified difficulties within the group and taking into account individual difficulties, one may build competences at different levels, facilitating the marked improvement in the confidence and competence of students as text producers.

\section{REFERENCES}

Adam, J.-M. (1992). Les textes: types et prototypes. [Text : types and prototypes] Paris: Nathan.

Adam, J.-M. (1993). Le texte et ses composantes: théorie d'ensemble des plans d'organisation. [The text and its components: general theory of organizational plans] Semen, 8, from http://semen.revues.org/document4341.html.

Adam, J.-M. \& Petitjean, A. (1989). Le texte descriptif. [The descriptive text] Paris: Nathan.

Ajideh, P. (2003). Schema theory-based pre-reading tasks: a neglected essential in the ESL reading class. The reading matrix: an international online Journal, 3(1), 1-14.

Bartlett, F. C. (1932). Remembering. Cambridge: Cambridge University Press.

De Beaugrande, R. \& Dressler, W. (1981). Introduction to text linguistics. London: Longman.

Bereiter, C. \& Scardamalia, M. (1987). The psychology of written composition. Hillsdale, New Jersey: Erlbaum.

Cardoso, A. \& Silva, A. (2003a). O texto informativo / explicativo no $1^{\circ}$ Ciclo [Explanatory/informative texts in the 1st cycle of primary education]. In C. Mello, A. Silva, C. Lourenço, L. Oliveira \& M. Araújo e Sá (Eds.). Didáctica das línguas e literaturas em Portugal: contextos de emergência, condições de existência e modos de desenvolvimento. Coimbra: Pé de Página Editores, 75-80.

Cardoso, A., \& Silva, A. (2003b). Problemas na produção e compreensão do texto explicativo [Problems regarding the production and comprehension of explanatory text]. In A. Bárrios \& J. Ribeiro (Eds.). Criatividade, afectividade, modernidade - construindo hoje a escola do futuro. Lisboa: CIED - Escola Superior de Educação de Lisboa, 211-229.

Chapman, M. (1995). The sociocognitive construction of written genres in first grade. Research in the Teaching of English, 29, 164-192.

Chapman, M. (2006). Research in writing, preschool through elementary, 1984-2003, L1 Educational Studies in Language and Literature, 6(2), 5-27. 
Coltier, D. (1986). Approches du texte explicatif. [Approaches to explanatory texts] Les textes explicatifs, Pratiques, 51, 3-22.

Costa, M. L. \& Pereira, S. (2003). O Texto Descritivo no $1^{\circ}$ Ciclo do EB: implicações pedagógicodidácticas [Descriptive texts in the 1st cycle of primary education]. In C. Mello, A. Silva, C. Lourenço, L. Oliveira \& M. Araújo e Sá (Eds.). Didáctica das línguas e literaturas em Portugal: contextos de emergência, condições de existência e modos de desenvolvimento. Coimbra: Pé de Página Editores, 131-137.

Departamento da Educação Básica [1998] (2004). Organização Curricular e Programas: $1^{\circ}$ Ciclo do Ensino Básico [Curricular organisation and programs: 1st cycle of basic education]. Lisboa: Departamento da Educação Básica, $4^{\mathrm{a}}$ edição.

Departamento da Educação Básica (2001). Currículo Nacional do Ensino Básico - competências essenciais [Curriculum for basic education - essential competences]. Lisboa: Departamento da Educação Básica.

Dickson, S. V., Simmons, D. C. \& Kameenui, E. J. (2007). Text organization and its relation to reading comprehension: a synthesis of the research, from http:idea.uoregon.edu/ ncite/documents/techrep(tech17.html.

Englert, C. \& Thomas, C. (1987). Sensitivity to text structure in reading and writing: a comparison between learning disabled and non-learning disabled students. Learning Disability Quaterly, 10, 93-105.

Fayol, M. (1986). Les connecteurs dans les récits écrits - étude chez l'enfant de 6 à 10 ans [Connectors in written stories - study in children from 6 to 10 years old], Pratiques, 49, 101-113.

Fayol, M. (1997). Des idées au texte [From ideas to text]. Paris: P.U.F.

Fayol, M. (2000). Comprendre et produire des texts écrits: l'exemple du récit [Understand and produce written texts: the example of narrative]. In M. Fayol \& M. Kail (Eds.). L'acquisition du langage. Paris: P.U.F., 183-213.

Fterniati, A. \& Spinthourakis, J. (2004). L1 Communicative-textual competence of Greek upper elementary school students. L1--Educational Studies in Language and Literature, 4 (2-3), 221-240.

Grize, J. (1981). Logique naturelle et explication [Natural and logical explanation], Revue européenne des sciences sociales, 56, Tome XIX.

Halliday, M. A. \& Hasan, R. (1995). Cohesion in English. New York: Longman.

Hayes, J. R. (1996). A new framework for understanding cognition and affect in writing. In C. Levy \& S. Randell (Eds.). The science of writing: theories, methods, individual differences and applications. Mahwah: LEA, 1-28.

Hayes, J., \& Flower, L. S. (1980). Identifying the organization of writing processes. In L. W. Gregg \& E. R. Steineberg (Eds.). Cognitive processes in writing. Hillsdale: New Jersey, LEA, 3-30.

Hickmann, M. (2003). Children's discourse - person, space and time across languages. Cambridge: Cambridge University Press.

Karmiloff-Smith, A. (1986). Some fundamental aspects of language development after age 5. In P. Fletcher \& M. Garman (Eds.). Language acquisition. Cambridge: Cambridge University Press, 455-474.

Labov, W. (1972). Langage in the inner city: study in the black English vernacular, Philadelphia, University of Pennsylvania Press.

Larivaille, P. (1974). L'analyse (morpho)logique du récit [(Morpho)logical analysis of narrative]. Poétique, 19, 368-388.

Li, X.; Wu, J. \& Wang, W. (2007). Analysis of schema theory and its influence on reading. US-China Foreign Language, 5(11), 18-21.

Milner, J.-C. (1982). Ordres et raisons de langue [Orders and reasons of language]. Paris: Seuil.

Negro, I., \& Chanquoy, L. (2005). The effect of psycholinguistic research on the teaching of writing. L1-Educational Studies in Language and Literature, 5, 105-111.

Pereira, S. \& Costa, M. L. (2003). A produção do texto descritivo no $1^{\circ}$ Ciclo: detecção de alguns problemas. [Problems regarding the production of descriptive text in the 1st cycle of primary education]. In A. Bárrios \& J. Ribeiro (Eds.). Criatividade, afectividade, modernidade - construindo hoje a escola do futuro. Lisboa: CIED - Escola Superior de Educação de Lisboa, 193-210.

Schneuwly, B.; Rosat, M.-C. \& Dolz, J. (1989). Les organizateurs textuels dans quatre types de textes écrits. Étude chez des élèves de dix, douze et quatorze ans [Text organizers in four types of written texts. Study of ten, twelve and fourteen years old students]. Langue française, 81, 40-58. 
Slot, M. F. (2006). Development of textual competence during students' work with multimodal learning material. In B. Éric; A. Bente; K. Susanne, \& H. Mike (Eds.). Caught in the web or lost in the textbook? STEF, IARTEM, IUFM de Basse-Normandie, Paris: Jouve, 475-480.

Smagorinsky, P. (2006). Writing in School Contexts. L1 Educational Studies in Language and Literature, $6(2), 1-6$.

Sousa, O. (1996). Construindo histórias [Building stories], Lisboa: Estampa.

Sousa, O. \& Silva, M. E. (2003a). Fundamentos linguísticos para a prática do texto narrativo no $1^{\circ}$ Ciclo [The narrative text: classroom practices in the 1st cycle of primary education]. In C. Mello, A. Silva, C. Lourenço, L. Oliveira \& M. Araújo e Sá (Eds.). Didáctica das línguas e literaturas em Portugal: contextos de emergência, condições de existência e modos de desenvolvimento. Coimbra: Pé de Página Editores, 139-143.

Sousa, O. \& Silva, M. E. (2003b). O texto narrativo no $1^{\circ}$ Ciclo: detecção de alguns problemas [Problems regarding the narrative text in the 1 st cycle of primary education]. In A. Bárrios \& J. Ribeiro (Eds.). Criatividade, afectividade, modernidade - construindo hoje a escola do futuro. Lisboa: CIED - Escola Superior de Educação de Lisboa, 181-192.

Ucha, L. (Ed.) (2007). Desempenho dos alunos em Língua Portuguesa - ponto da situação [Assessment of students' competences in Portuguese L1]. Lisboa: Ministério da Educação Direcção-Geral de Inovação e de Desenvolvimento Curricular.

Van Dijk, T.A. (1980). Macrostructures: An interdisciplinary study of global structures in discourse, interaction, and cognition. Hillsdale, New Jersey: Erlbaum.

Van Dijk, T.A. (1986). Text and context. Explorations in the semantics and pragmatics of discourse. London / New York: Longman. 